\title{
Primary causality: In defence of the metaphysical rationality of faith in God as Creator
}

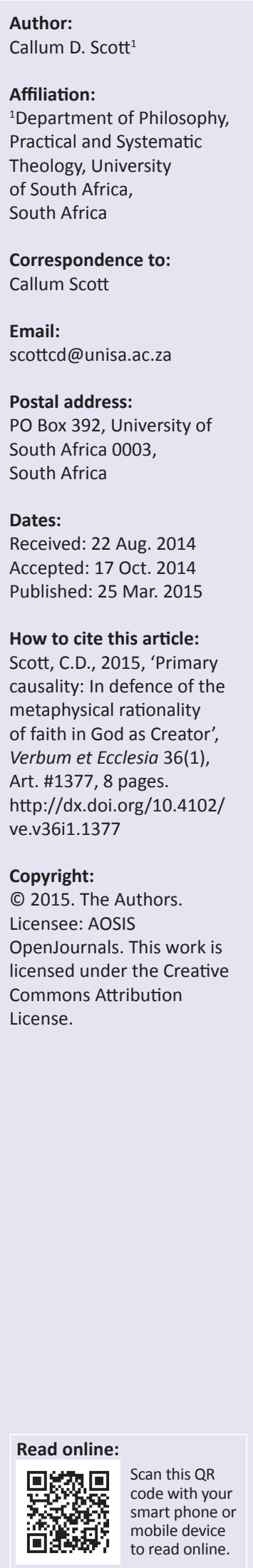

Support has been lent to contemporary 'New Atheism' from physicalist interpretations of 'hard' science. From this perspective, any system of knowledge that does not rely solely upon empirical method is deemed meaningless in comparison to observationally-grounded empirical science. Consequently, as a non-empirically-based approach, faith positions are included in the critique offered by physicalists. The impetus for this article, then, is to establish physicalism as a reductionist epistemology that is partially comprised of - seemingly inconspicuously embedded - metaphysical assumptions. With metaphysics apparent in 'hard' science, it is argued from a Thomist perspective that metaphysical themes of primary causality must be realistically considered to account for being. As a logical outcome, the proposal is made that metaphysical primary causality directs to the reasonable suggestion that God creates.

Intradisciplinary and/or interdisciplinary implications: This article specifically challenges the currently trendy 'New Atheist' school of thought, resting upon the counter-argument offered that 'hard' science cannot ultimately account for the emergence or continued existence of being. Utilising Aquinas, the research calls for a re-embracement of unified, as opposed to limited, systems of knowledge.

[T] he question 'Why is there anything at all?' is quintessentially mystical ... [in] that it apparently has no possibility of an answer. Whatever answer it would have to be something in the world, or else something other than the world, and the question would just reappear over the existence of that other thing. (Smart 1996:35-36)

\section{Introduction ${ }^{1}$}

There are current schools of thought that consider 'hard' science as the resolution to the primordial metaphysical problem. Amongst these are the physicalists and their supporters, the 'New Atheists'. ${ }^{2}$ Physicalism, however, relies upon a misconceptualisation of the problem by reducing the emergence of being to empiricism, for in these accounts, being is construed as arising from a change in material form. ${ }^{3}$ Thus, physicalists conjecture that the 'problem of creation' is not metaphysical and can be removed from speculation as 'hard' science accounts for the emergence of being. ${ }^{4}$ The physicalist position argues further that God's existence is impossible because there is no role for a creative agent in a self-causing cosmos.

If, however, the physicalist position is problematised in terms of its own foundational metaphysical positions, some way toward the validation of metaphysics as relevant to the knowledge economy would have been obtained. In a stronger vein, metaphysics would be demonstrated as irremovable as it concerns the very foundation of being. ${ }^{5}$ The following problem would then ensue: If metaphysics is not removable, is it reasonable to postulate that a primary, metaphysical cause brought about contingent being within space-time?

\footnotetext{
1.Some of the ideas in this article were initially developed in the author's D.Phil. (Philosophy) at the University of Pretoria.

2. "Why does something exist rather than nothing?" ... [G]iven that things have to exist, we may be able to give a reason why they have

to exist as they are ...' (Leibniz [1698] 2006).

'The spontaneous genesis of something out of nothing happened in a big way at the beginning of space and time, in the singularity known as the Big Bang followed by the inflationary period ...' (Dawkins in Krauss 2012:189).

'We can describe the evolution of the universe back to the earliest possible moments of the Big Bang without specific need for anything beyond known physical laws ...' (Krauss 2012:145).

' $[T]$ he beginning of the universe was governed by the laws of science and doesn't need to be set in motion by some god' (Hawking \& Mlodinow 2010:135)
}

3.An example of this argument is the theory that the initial singularity emerged out of quantum fluctuation (Davies 1998:233-235).

4.'[O]ur real problem will not be to understand the beginning of the universe, or even to decide whether there really was a beginning ' (Weinberg 1993:191).

5.'Philosophy always buries its undertakers' (Gilson [1937] 1999:246). 
This article attempts to re-establish the importance of metaphysics for causal explanation and to consider potential cause for the emergence of being, a cause upon which all things that hold contingent being depend. Whilst not developing a proof for God's existence, it will be argued that the theistic account provides the best available approximation for contingent existence, that is, for the 'problem of creation'. This is because the provision of grounds that account for being is, in the author's view, considerably more satisfactory than the physical appeal to 'creation' from causally unaccounted for physical processes.

\section{Metaphysics for the existence of particularities}

'Hard' science is bound to remain within the delimited scope of the empirically verifiable because that which cannot be measured cannot have the scientific method employed upon it (Medawar 1984:81, 86; Russell 2008:12). ${ }^{6}$ In the particular case of the emergence of being, however, there is no empirical evidence available for study. Indeed, even if the beginning of the present universe were causally tied to the original moments of the existence of being, data concerning the preinflationary epoch of the cosmos is unattainable as it was destroyed in the post-inflationary decay (Barrow 2005:168 169). Therefore, falling outside of the boundaries of science, the 'problem of creation' cannot be considered as a scientific problem. In point of fact, empirical science does not aid in the understanding of any primary causal agent with the potential to bring being into existence (MacIntyre 2009:77).

Because of the lack of measurable phenomena, physicalists have merely dismissed the metaphysical problem in current works. ${ }^{7}$ Certainly, from this interpretation of 'hard' science, being is simply without explanation. ${ }^{8}$ However, dismissiveness does not account for being's existence, save for an appeal to circular rationality in physicalist arguments. Were no appeal to be made to a transcendent, no argument could be given that accounts for the act of bringing about existence from nothingness. Thus, all things within the approximately 13-billion year history of the universe remain metaphysically unexplained but physically evident. ${ }^{9}$

Although physicalists hold that pursuing constructs that transcend what is observable with the senses are wasted enterprises in conjecture, we posit an alternative paradigm that incorporates both the empirically verifiable and the logically conceivable. Marcel ([1950] 2001:46) puts it as follows: '[T]he judging of something to be outside experience is itself empirical, that is to say it is a judgement made $6 . '[$ Problems] cannot at one and the same time qualify as authentic scientific questions
and be such that their answers lie in principle beyond the reach of science' (Rescher 1984:131).

7.cf. Dawkins in Krauss (2012); Hawking and Mlodinow (2010); Krauss (2012) and Weinberg (1993)

8.'As far as empirical science goes, existence is just a matter of fact' (Lonergan [1957] 1970:654).

9.Physicalist appeals to a self-causing universe leave the universe existing without expanding upon how extant material processes came to have existence and themselves later acted upon matter to effect further developments within space-time. from within experience [about what is non-experiencable].' Positivism, physicalism's precursor, curbed experience to what is perceptible with the senses, making the claim that all theoretical constructs are bound to sensory empiricism (Marcel ibid:47). As a consequence, all empirical studies and their ontological contents are reduced to one-dimensional physicalism (Marcel ibid:47). Attempting to access empirically transcendent knowledge does not mean abandoning experience for embodied minds must always be reliant upon the experiencing body for understanding (Marcel ibid:47). However, the caveat should be observed that, in understanding, thinking subjects must be cautious not to impose human limits upon being. Rather, then, knowledge acquisition must be reimagined on the terms of the complex wholeness of being rather than upon humanity's bounds. This necessitates an awareness of the transcendent 'otherness' of the non-experienced aspects of being from the bounded experience of the thinking subject (Marcel ibid:48). More specifically, it denotes a thorough turning toward 'being' - as being is - unhampered by the limits of the possibly knowable. ${ }^{10}$

In the metaphysical sense, immanent experience originates in what is known primarily and most universally, that is, transcendent being (Maritain [1959] 1995:224). This is because every experience of a particular - by the fact that it is experienced - directs beyond the particularities of the immanent thing itself toward the more universal, transcendent reality that that thing has existence. ${ }^{11}$ In other words, it is the universal existence of all particularity that precedes the particularities of the existing thing. ${ }^{12}$

The metaphysical dimension of philosophy emerges as the sole port of entry for a discourse that relates to knowledge of the universally transcendent from that of sensed particularities (Blanchette 2007:145). From consideration of the experiential, the philosopher - by posing questions that relate to the apparent but transcend it - is pushed to transcendence of particularities (Blanchette ibid:145). Within this reasoning beyond the physicalist's limits of temporality, the metaphysician can postulate the existence of causal agency, un-bound by space-time, a 'transcendent ground of being' that is necessary to explain being's existence (Blanchette ibid:145). ${ }^{13}$

\section{The problem of primary causality}

The study of the transcendent imposes a limit on the scholar by exceeding sensory experience (Burrell 2010:49). This is

10.'The object of metaphysics ... is an entirely other world, the world of the superuniversal, the world of transcendental objects which ... offer a field of intelligibility which has in itself its own ultimate determinations' (Maritain [1959] 1995:231).

11.'[A]mong all effects the most universal is being itself ...' (Aquinas Summa Theologica, I, Q. 45, A. 5; Maritain [1959] 1995:226).

12.'When I look at a man and think: "This is a being", or "He exists", I grasp a certain determinate being, finite, perishable, fleshly ... subject to time ... and a certain existence similarly qualified. But the analogous object "being", "existence", thus thought by me outreaches this analogate' (Maritain [1959] 1995:226).

13.This postulated metaphysical agency is analogous to the faith-proposition that 'God created' as the God-creator is a fully transcendent reality. Indeed, as metaphysics directs to a transcendent cause, similarly, transcendence is an essential aspect of religious belief. '[T]ranscendence is presupposed in properly religious belief' of religious belief. '[T'
(Blanchett 2007:145) 
acutely illustrated in the empirically transcendent nature of statements concerning primary causality. For instance, Sacred Scripture non-empirically asserts the utterly transcendent. ${ }^{14}$

From the perspective of Judaeo-Christianity, the postulate is held that the act of creation precedes all things within space-time. ${ }^{15}$ No created thing - it is proposed - can bring forth being from not being, that is, can create. Hence, JudaeoChristianity argues for a cause of being that transcends the created for the created cannot bring itself or anything else into existence (Aquinas Contra Gentiles, I, Ch. 49, §4).

Rather than rejecting empirical modes of knowledge acquisition in gaining knowledge of the transcendent, Saint Thomas Aquinas utilised both observation and reason to establish that, from the existence of things, the existence of a first cause - as cause of the experienced - could be proffered (Kretzmann 2001:33). ${ }^{16}$ Aquinas employed one of the four Aristotelian causes, namely the concept of efficient causality, to argue for this stance. ${ }^{17}$ In terms of efficient causality, Aquinas put forth that the first cause resorts, because of the evidence of the creative action, in the fact that things have being and that they require account for their existence (Aquinas Contra Gentiles, I, Ch. 79, §2; Kretzmann 2001:33). ${ }^{18}$

As time-bound, the sequential progression of efficient causality would cease were any particular cause in the progression of causality to be removed. Thus, within the causal change, there must be intermediate causes and an initial efficient cause that brings about being. Without this efficient cause no other thing could be. The cause behind all causality must, of necessity,

14.'In the beginning ... God created ...' (Genesis 1:1, The New American Bible, Revised Edition). The theme of creation draws out the distinction which Aquinas develops between primary and secondary causality. He (Aquinas Summa Theologica, I) articulates it thus:

$[T]$ o create can be the action of God alone. For the more universal effects must be reduced to the more universal ... causes ... [A]mong all effects the most universal cause ... [However, another] secondary instrumental cause does not participate in the action of the superior cause [which is the bringing about of participate in the action of the superior cause [which is the bringing about of
being, but only] acts dispositively to the effect of the principal agent. (Q. 45, A. 5)

Whilst a secondary cause can act upon a thing, the being of the thing which is produced by the act of the primary cause precedes the secondary cause. In this manner, the secondary cause of, to use Aquinas' example, the act of sawing wood to produce an item of furniture is secondary because it acts upon what already has primary existence, namely, the wood, constituted by primary matter (I, Q. 45, A. 5).

15.' $[T]$ he act of being ... is caused by creation, which presupposes nothing; because nothing can pre-exist that is outside being as such' (Aquinas Contra Gentiles, II Ch. 21, §4).

16.'Not only does faith hold that there is creation, but reason also demonstrates it (Aquinas Writings on the Sentences, II, distinction 1, Q. 1, A. 2 in Baldner \& Carrol 1997:75).

17.'[Efficient causes refer to $t$ ] hat from which the change or the resting from change first begins; e.g. ... the father [is] a cause of the child ...' (Aristotle Metaphysics, Book 5, Part 2).

18.The Aristotelian definition of 'efficient causality' refers to the particular efficient cause of a change effecting a thing (Aristotle Metaphysics, Book 5, Part 2). cause of a change effecting a thing (Aristotle Metaphysics, Book 5, Part 2). Aquinas, however, expands the Aristotelian notion to include first causality whils draw a distinction betwe core idea of Aristotle. We are compelled therefore to draw a distinction between first efficient causality and what may be deemed as secondary efficient causality, that is, efficient causality that relates to changes in extant matter. First efficient causality can be defined as the production of being of entities that are dependent for their existence upon a first cause.

Aristotle determined that efficient causality cannot be regressive to infinity for if it were the case that no primary efficient cause could be identified then no later causes in the chain of causal events could be known (Aristote Metaphysics, It, la, causes in the chain of causal events could be known (Aristotle Metaphysics, II, la, 2, Aquinas Contra Gentiles, 1, Ch. 13, $\$ 33$ ). Within a time (a) causes (Aristotle Metaphysics, II, la, 2, Aquinas Contra Gentiles, I, Ch. 13, §33). As such, were the first efficient cause in the chain of causes removed, no othe subsequent cause could be (Aquinas Contra Gentiles, I, Ch. 13, §33). transcend the created boundaries of space and time which it brings about. The first, primary efficient cause should, thence, satisfy the conditions of being both non-created and nontemporal such that it could bring forth being where being was not, that is, to create rather than changing the form of what already exists (Aquinas Contra Gentiles, II, Ch. 21, §1). Hence, in the Thomistic conception, the 'problem of creation' that requires a metaphysical solution for a material attempt that appeals to physical entities that also require causal account simply does not suffice (Aquinas Contra Gentiles, II, Ch. 21, §1).

Thomistically defined, 'creation' is the primordial action that brought about the being of space-time and matter. ${ }^{19}$ There can, from this definition, be no action prior to creation, for before creation there was nothing material. Thus, metaphysically construed, it is solely dependent upon the act of creation that all beings have their existence (Aquinas Contra Gentiles, II, Ch. 21, §3). For Aquinas, it is unreasonable to assert that the act of creation - bringing into being - occurred without a cause responsible for the action (Aquinas Summa Theologica, I, Q. 44, A. 1). He expands upon this point by considering the existence of particular entities (Aquinas Quaestiones Disputatae de Potentia Dei):

[I]f in a number of things we find something that is common to all, we must conclude that this something was the effect of some one cause: for it is not possible that to each one by reason of itself this common something belong, since each one by itself is different from the others: and diversity of causes produces a diversity of effects. Seeing then that being is found to be common to all things, which are by themselves distinct from one another, it follows of necessity that they must come into being not by themselves, but by the action of some cause. (Q. 3, A. 5)

All things that exist share in the most primordial commonality, namely being. Now, the bringing into being requires an enactor behind the act, for nothing that has been created can create, and nothing merely has being that is not the result of primary causal activity, unless it is possible for an action to occur without cause.$^{20}$ It can, therefore, be conjectured that the cause of primary being must not be space-time or materially bound, as each of these are created entities. This causal agent is conceptualised as 'God', for 'God, by definition, is a being unlike any other in created space-time. '... God creates things, from the fact that there can be nothing besides Himself that is not caused by Him ... only He is the universal cause of being' (Aquinas Contra Gentiles, II, Ch. 21, §3). ${ }^{21}$

19.The dogma of creation is central to Christian creeds (Clarke 2007:99-100). As a Christian, Aquinas would have sought to defend this.

20. 'Nothing happens without a cause, but everything with a cause and by necessity' (Leucippus in Dampier 1966:23).

21.All linguistic entities are cognitive. Thus, the linguistic symbol does not hold the signified an sich. Rather, the linguistic conformation is never absolute but always only to some degree as it is the construct of the language user in an encounter with the particular thing construed linguistically. The thing is hence - in realist terms - something like the signified, but is never the signified itself. " $T T$ hings are terms - something like the signified, but is never the signified itself. ' $[T]$ hings are
said of God and creatures analogically, and not in a purely univocal sense' (Aquinas Summa Theologica, I, Q. 13, A. 5)

Whilst Aquinas considered all language as analogical, the analogical distance between signified and signifier varied in degree relative to the experience of the ignified. Although the concept of "tree' is an connted. Although the concept of 'tree' is analogical, the extent of the analogical content would be ' $G$ d' (ibid I, Q 13, A. 5). Although the is a distan, metaphysica construct, such as ' $\mathrm{God}$ ' (ibid I, Q.13, A. 5). Although there is a distance between the analogical content of the term 'tree' and the tree itself, this is considerably less than the vast space between the transcendent nature of God, for example, whose essence
far transcends what can be contained in the signification 'God' (ibid I, Q. 13, A. 5). 
There is an extensive anti-theological claim that God does not create (Aquinas Quaestiones Disputatae de Potentia Dei, Q. III, A. 5; Aquinas Summa Theologica, I, Q. 44, A. 1 and A. 2). Of course, this position fails to discern the distinction between primary and secondary causality. Nevertheless, in his works, Aquinas resolutely asserts that the existence of being requires an appeal to primary causality because its - the existence of being's - explanation, that there is no temporal being within space-time, is its own primary cause for existence rather than for non-being (Aquinas Summa Theologica, I, Q. 44, A. 1). '[A created] being cannot be without being caused' (Aquinas Summa Theologica, I, Q. 44, A. 1).

Some of the points of critique aimed at creation theories such as that of Aquinas are centred upon eternity. This position assumes that a universe with no boundary existed forever, so removing the logical requirement for a cause of creation conceptualised as a single action. In this view, no creation event happened, and there is only the extant within spacetime (Hartle \& Hawking 1983:2974-5; Hawking 1985:12; Susskind 2012). In a model of eternal matter, the regress to earlier secondary causality would never apprehend primary causality due to infinity's unapproachable nature. Moreover, because matter is construed as eternal, there is no recourse to a creator (Hawking, 1988):

So long as the universe had a beginning, we could suppose it had a creator. But if the universe is really completely self-contained, having no boundary or edge, it would have neither beginning nor end: it would simply be. What place, then, for a creator? (pp. 140-141)

Nevertheless, this theory is weakened when its hypothetical nature is made apparent. ${ }^{22}$ It should be recalled that wellsupported physical theories put forth that all that exists is time-bound, as opposed to a boundaryless universe, for space-time emerged within finite time at the beginning of the initial singularity (according to the standard model) (Davies 1998:226; Hawking \& Ellis 1973:364; Penrose 2004:704; Roos 2008).

Despite its appeal to atheistically supported cosmological models, however, even if the eternal matter argument is plausible, it does not remove the fundamental metaphysical problem: Why is there anything at all? ${ }^{23}$ Assuming the truth of the no-boundary models, in a demonstrable manner, no matter can be changed without matter existing prior to the act of change. Any material change is the product of secondary causation for the matter upon which the making occurs is present prior to the act of change. Indeed, if matter was unmade and eternal, its causality remains unaccounted for no material thing can bring a thing of its own kind into existence. $^{24}$

22. The ground-state wave function in the ... model that we have considered ... does not correspond to the quantum state of the Universe that we live in because the matter wave function does not oscillate' (Hartle \& Hawking 1983:2975).

23.' $[F]$ rom nothing comes nothing, is true as regards ... particular making ...' (Aquinas Contra Gentiles, II, Ch. 37, §3).

24.'[T] he word making implies motion or change, whereas in the origination of all being from one first being, the transmutation of one being into another is ... inconceivable' (Aquinas Contra Gentiles, II, Ch. 37, §3).
In our estimation, the consideration of ultimate existence as the product of physical processes (making) as opposed to the bringing forth of being results in an argument of the strawman variety for the fundamental issue - the metaphysical problem - is pushed aside in the response. Hence, we argue, the existence of being has not been explained in the nixing of the appeal to transcendent primary causality by rejecting the possibility of creation.

\section{Seeking primary cause in the act of creation}

[M]an cannot obtain the knowledge of God by natural reason except from creatures. Now creatures lead us to the knowledge of God, as effects do to their cause. (Aquinas Summa Theologica, I, Q. 32, A. 1)

Looking for primary causality to account for being was apparent from the earliest times of theological discourse on nature in Saint Ephrem the Syrian (4th century AD).$^{25}$ Later, scientists of early Modernity like Isaac Newton and Galileo Galilei both embraced natural theology to explain existence. ${ }^{26}$ Unfortunately, the materialist might of philosophical and scientific discourse had the effect that only a few theologians continued arguing the case for God as perceivable within being (Nichols 2010:156-157).

Certainly, after the 18th century's metaphysical impasse argued by Kant, the mind's movement from nature to God became impossible (Haldane 1996:148; Hampson 2009:65). Although Kant did not side-line metaphysics, his epistemology argued that the thinking subject could no longer transcend the appearance of the object to grasp the Ding an sich, let alone the causality of the thing (Kant [1783] 2007:2-3). The Kantian legacy, coupled with physicalism accounting for all explanation, led to God becoming epistemologically both inaccessible and redundant (Nichols 2010:160-161). However, neither anti-transcendental epistemology nor physicalism gives adequate explanation for the fundamental metaphysical problem, namely that being remains without explanation. ${ }^{27}$

An epistemological consideration of physicalism makes it abundantly clear that there are presuppositions behind its approach to knowledge acquisition. For instance, it assumes that all human knowledge is empirical (Haldane 1996:149). Furthermore, physicalism metaphysically presumes that there are extant entities that can be studied

$25 .[T]$ he book of creation ... has in its narrative made the Creator perceptible ... it has envisioned all His craftsmanship, made manifest His works of art' (Saint Ephrem the Syrian 1990:108-109).

26.The following citations indicate the natural theology apparent in the works of Newton and Galileo:

'This most beautiful system of the sun, planets, and comets, could only proceed from the counsel and dominion of an intelligent and powerful Being' (Newton 1846:504).

'To prohibit ... science would be no different than to reject hundreds of statements from the Holy Writ, which teach us how the glory and the greatness of the supreme God are marvellously seen in all of His works and by divine grace are read in the open book of the heavens' (Galilei [1615] 2008:128)

27.'[Scientific c] osmology ... has not succeeded in explaining the origin of the universe. The purported answers do not answer the question, but simply push it back to earlier unobservable stages ...' (Nichols 2010:171). 
and that the human thinking subject has access to these in an unhampered manner. These undergirding factors draw out the non-empirical foundations of this approach to knowledge. Therefore, an analysis of physicalist reductionism demonstrates a problem in its presupposition, namely that human knowledge is necessarily empirical (Haldane ibid:149). If physicalism relies on the non-empirical, the non-empirical should not be conceived as unreliable as the physicalists would have one hold for the physicalists exalt their own approach to knowledge that incorporate the non-empirical. We put forth, therefore, that, if not all knowledge has an empirical base, then empirical reductionist anti-transcendentalism is a weak approximation of the nature of systems of knowledge. This is especially apparent in the rejection of primary causality without which secondary causes - the particular focus of empirical science - would not have being.

Notwithstanding the point that the fundamental metaphysical question has been ignored, the problem of being continues to stand. Essentially, this research has demonstrated that no reductionist theory has the capacity to account for being..$^{28}$ It is hence that we turn to a non-reductionist stance that takes the metaphysical problem seriously (Murphy 2008:114).

It is accurate to assert that the evolutionary development of the cosmos can be accounted for by natural, causal theories without appeal to any supernatural being (Peacocke 2008:201). This, though, is not a theory of the emergence of being for it rather refers to the changes in what has existence already. Therefore, a more primary explanation had to be sought to account for material existence and that of natural processes, too. This required explanation is not satisfied by a theoretical construct of the 'God-of-the-gaps' variety, however, as naïve religion argues. God conceived in this 'stop-gap' way - that is, God that accounts for present voids in scientific explanation - will always be superseded by future scientific theories. ${ }^{29}$ The 'God-of-the-gaps' equates to natural principles of change in material form, but these must themselves be brought about by primary causal action. In effect, non-creative, natural principles are secondary causes utilising already existing matter. ${ }^{30}$

The interventionist 'God-of-the-gaps' that makes himself apparent in natural and supernatural processes enables no distinction between primary and secondary causality for God interjects at any moment of cosmic history. The Thomist distinction, however, between the types of postulated causality, considers an action to be at the source of being's coming to be (Aquinas Summa Theologica, I, Q. 45, A. 5).

28.[C] osmology and physics will never be able to describe or model the ultimate cause of the universe, nor of the laws of nature - that which effects the transition from absolute nothingness to existence and that which grounds the order of what exists' (Stoeger 2008:230)

29.'[T] he successes of the sciences in unraveling the intricate ... web of relationships between structures, processes and entities in the world have made it increasingly problematic to regard God as intervening in the world to bring about events that are not in accordance with these ... regularities that the sciences increasin unravel ... [T] he whole epic of evolution from the "hot big bang" to humanity has

30.Aquinas Contra Gentiles, II, Ch. 37, §3; Aquinas De Potentia, Q. III, A. 5; Aquinas Summa Theologica, I, Q. 44, A. 1 and Stoeger (2008:225).
Furthermore, it views secondary causality as non-equitable with primary causality for whilst the latter brings forth being secondary causality only effects changes in matter that has already been ascribed being (Peacocke 2008:203; Stoeger 2008:225). If God is to be construed as first cause, the limited, interventionist 'God-of-the-gaps' is not this God. ${ }^{31}$

Thus, we argue, that as primary causality remains unexplained after the research of 'hard' science had been done - because primary causality lies outside of the scope of the competence of 'hard' science by its metaphysical natureit is consistent to posit the metaphysical assertion that a primary cause from outside of material reality brought about being from not being. Indeed, were a first agent not the case, primary causality would require an alternative explanation for its being, a cause that itself transcended the limits of the possibility of pre-extant matter creating. The identification of 'God' as creator does not, however, empirically prove God's existence. This is a reasonable article of faith.

The argument that 'God' is the most fitting explanation for being is problematic, principally - in a misconstrued understanding of the delineation of science from nonscience - because it is void of empirical support. It is thus open to decimation as has been done by '... New Atheists who have argued that faith has no relevance at all in current times' (Hitchens 2007:282-283). Nevertheless, to negate the postulate that creation is an act of God is not as easy as a flippant rejection. A removal of the assertion that creation is the product of the action of God implies that one would need to disprove God's existence as all being is the product of primary causality. It is the identificatory link between the cause of being and being caused by the non-space-time bound 'God' that requires breaking down.

To disprove that God exists requires knowledge of all possible things, after which one could empirically declare that amongst all known entities, God is not to be found (Spitzer 2010:230). ${ }^{32}$ However, the thinking subject contextualised within the sheer magnitude of the cosmos suggests that knowledge of all that exists is nothing more than idealistic conjecture (Spitzer 2010:230).

God, however, could be disproven by showing that the category 'God' has a boundary excludable from the category 'being' (Spitzer 2010:230). This would make God's existence contradictory to knowledge that conforms to what falls within the category of 'being' (Spitzer ibid:230-231). However, the establishment of the boundary of the 'God' category is impossible as per the definition employed because God is transcendent - without space-time - and so is not bound by temporal limits to definitions of categories (Spitzer ibid:231).

31.A God who intervenes could only and rightly be regarded ... as being a kind of semimagical arbitrary Great Fixer or occasional Meddler in the ... created, natural and historical networks of causes and effects' (Peacocke 2008:205).

32.The argument can be reconstructed in syllogistic format:

1. All knowledge about reality is known.

2. No knowledge of God can be found from within all knowledge.

3. Therefore, God does not exist, and the non-existent cannot be the primary cause of being. 
The identification of the categorical difficulties with attempts at disproving God's existence leads to the conclusion that, whilst not an absolute statement of certitude, God cannot be discounted as the primary cause of contingent being.

\section{The argument for being's quotidianness}

A proliferation of counter-arguments persists in trying to disprove God, attempting to demonstrate, by extension, that being does not have a transcendent cause. Whilst universal being has been the concern of the present argument, physicalists elect to focus upon the immediately observable: particularities. However, our awareness of being in its broader context results in perpetual consciousness of the problem of primary causation as opposed to a preoccupation with immediate causality upon a particular entity.

As has been argued, Thomism presumes that the progression from the thinking subject's experience of things to things' cause of being is reasonable. However, there is a distance between the thing experienced through the senses and the postulate that a thing is caused by an agent outside of the sensory reach of the thinking subject. Hence, can it be established that nature leads to knowledge of 'God' as transcendent cause? Empirical evidence for the identification of the primary cause as 'God' is not readily available. As a result, belief in 'God' as creator emerges solely from the non-sensory but rational perspective of faith. The utilisation of reason in the inference can lead to probable knowledge of a metaphysical variety. That all knowledge is always the best available gives some support to the inference. ${ }^{33}$

Physicalism, in itself, relies upon another non-empirical, metaphysical assumption, namely that the cosmos requires no explanation outside of itself for its existence. ${ }^{34}$ Essentially, if the universe is self-causing, a transcendent primary cause is superfluous.

From the notion that the cosmos is contingent in primary causal terms, we have put forth, however, that 'God' is the cause of being (Smart 1996:39). To the contrary, Smart argued that the necessity of God is a weak position (Smart ibid:41). According to Smart, the universe is the sole necessary, non-contingent entity (Smart ibid:41). ${ }^{35}$ Support for this assertion arises from there being no empirical evidence for anything existing outside of space-time (Smart ibid:41). Without a contingent universe - given that the

\footnotetext{
33.There is a precedent that entities that are not testable by the senses are utilised within 'hard' scientific theories, too. Atoms, subatomic particles, quanta, quarks, dark matter, et cetera are not directly observable through the senses but are nevertheless utilised in empirical science as if their certainty was based upon direct observation. Furthermore, in their initial postulations, they were not observable. Thus, that something is not empirically experiencable does not necessitate that the entity does not exist. Hence, the non-empirical cannot be indiscriminately disregarded.
}

34.Carroll (2011)

35.Smart (1996) did, however, let go of the distinction between primary and secondary causes in his argument. universe is non-contingent - there is no need for the action of God. However, that particular things within the cosmos cannot bring things into being illustrates the weakness of this argument.

However, a response to the atheistic counter-argument is unfalsifiable since the metaphysical is non-empirical. ${ }^{36}$ The universe's natural processes do contribute toward the emergence of further entities within the cosmos. Do these processes come into being themselves? Historical inspection of natural processes must direct to the questioning of primary matter out of which natural processes have given rise to changes in matter. Neither primary matter nor natural processes, however, have brought being forth from nothing! They can only exact change in extant matter. Instead, these must be the result of the creative act alone.

The question to be faced is whether the existence of being directs to the existence of God? Lonergan (1970:669) argues that knowledge of God emerges from knowledge of being. ${ }^{37}$ Knowing being assumes that being exists, as only the extant can be known as true. Hence, being exists prior to and independently of knowledge of being. Thus, in knowing being, the thinking subject conforms to what exists (Lonergan ibid:673). As the subject and the thing are both not responsible for the thing's existence, the conjecture is put forth that it is conditional upon something apart from particular being, upon an ultimate ground of being that '... overcomes contingence at its deepest level' (Lonergan ibid:657). Lonergan (ibid) further argues:

[I]f God's efficient causality presupposes the existence of some matter and was limited to fashioning and ordering it, then the existence of this matter would be unexplained; but what ultimately is unexplained, does not pertain to being: and so the alleged matter would prove to be nothing. (p. 663)

The appeal to a transcendent, necessary, primary cause relies upon knowledge beyond the sensory experience of the thinking subject. For if the primary cause is transcendent, it follows that claimed knowledge of that cause is transcendent knowledge. In the post-Humean and Kantian philosophical milieu this is a difficulty in that transcendent knowledge is not empirically founded..$^{38}$ However, contrary to critical modernity, we argue that contingency of being directs to intelligible transcendent knowledge (Lonergan 1970:634).

36."[Arguments for primary causality] all arise from a conviction that ... it is insufficient to fully understand what happens; we must also provide an explanation for why it happens ... [T] he ultimate answer to "We need to understand why the universe exists/continues to exist/exhibits regularities/came to be" is essentially "No we don't"' (Carroll 2011:n.p.)

37.'[T] he real is being, and apart from being there is nothing. Being is not known without reasonable affirmation, and existence is the respect in which being is known precisely inasmuch as it is affirmed reasonably' (Lonergan 1970:669).

38.Both Hume and Kant exhibited scepticism about metaphysical knowledge, the former more than the latter:

'Does ... [metaphysics] contain any abstract reasoning about quantity or number? No. Does it contain any experiential reasoning about matters of fact and existence? No. Then throw it in the fire, for it can contain nothing but sophistry and illusion (Hume [1748] 2008:86).

'By means of sensibility, therefore, objects are given to us, and it alone furnishes us with intuitions; by the understanding they are thought, and from it arise conceptions' (Kant [1787] 2010:43). 
Whilst knowledge of the immanent is empirically founded, immanent knowledge does transcend empirically received data. For instance, the mind's judging of sensory and perceptual contents moves beyond the empirical (Lonergan 1970:635). Reality, however, is constituted by empirically irreducible being. ${ }^{39}$ The possibility for transcendent knowledge is thus present throughout reality (Lonergan ibid:638). How is knowledge of being extrapolated from the experience of particulars (Lonergan ibid:641)? It is apparent in what 'being' is, namely, the class that contains all existing things (Lonergan ibid):

The pure notion of being ... is prior to understanding and affirming, but it leads to them for it is the ground of intelligent and critical reflection ... [B] eing is completely universal and completely concrete ... (pp. 642-643)

From sensory experience of particular instances of being, the awareness is raised of common abilities shared by particulars (Lonergan 1970:644). Therefore, through the declaration of being as the universal that comprises reality, the issue of the causality of being emerges for no particular being can bring forth being from not being, hence, making all being contingent for its existence. ${ }^{40}$ Indeed, being's dependence for existence gives rise to the possibility of the affirmation that being is the consequence of an act by a cause that is not of caused, primary matter (Lonergan ibid:657). Western theology calls this cause "'God", "necessary" [and] "outside" or "beyond" the natural world" (MacDonald 2009:xii).

However, is this transcendent cause knowable if human cognition does not transcend the thinking subject? (MacDonald 2009:xi) To know the primary cause is to move beyond imposed cognitive boundaries that cut immanence from transcendence (MacDonald ibid:xvii). Certainly, as the agent of primary causality, God must be neither immanent nor transcendent for from humanly perceived transcendent being God brings forth being that is experienced as immanent to the human. ${ }^{41}$ If there is no epistemologically constructed boundary separating immanence and transcendence, the problem of knowing what is construed as transcendent, as totally other, is avoided (MacDonald ibid:xviii). Aquinas endorsed such a reimaging (Aquinas Summa Theologica, I, Q. 12, A. 1).

Affirmed contingent being - as a real entity rather than a mere cognitive construct - deems causality as extant, pointing to the actuality of the agent-cause of existence (Lonergan 1970:669, 673). Being dependent for existence, therefore, enables the reasonable assertion that, since the knowable exists, it must have a cause that accounts for

\section{9.'[A]part from being, there is nothing' (Lonergan 1970:638)}

40.'If nothing existed, there would be no one to ask questions and nothing to ask questions about. The most fundamental of all questions, then, asks about existence yet neither empirical science nor a methodologically restricted philosophy can have an adequate answer' (Lonergan 1970:653).

41.A boundary extant that severs the immanent from the transcendent is a solely human construction (MacDonald 2009:xviii). its being because contingent being cannot create itself (Lonergan $i b i d):^{42}$

[I]f God's efficient causality presupposed the existence of some matter and was limited to fashioning and ordering it, then the existence of this matter would be unexplained [as there would be no primary cause thereof]; but what ultimately is unexplained, does not pertain to being: and so the alleged matter would prove to be nothing. (p. 663)

\section{Conclusion}

A trend has emerged for single-planed knowledge systems to side-line the problem of creation, which never fails to remain a fundamental philosophical and theological issue for being and its cause always endure. It has been proposed in this article that an analysis that tackles the theme of primary causality overcomes the apparent stalemate between physicalistically conceived 'hard' science and metaphysics by utilising both the observationally apparent from 'hard' science and the inferences of metaphysics concerning the nature of the perceived things themselves.

The re-embracement of metaphysics gave a possible solution to the 'problem of creation' that lies in the tradition of natural theology. Indeed, from the metaphysical need for an account of creation's transcendent causality, the argument for primary causation was upheld (Blanchette 2007:145). By asserting a cause transcendent to non-creating, imminent being, the resolution appeals to the history of philosophy wherein theoretical construction surrounding primary causality can be traced back to both Plato and the Stoics (Plato Timaeus, 39d-39e; Diogenes Laertius Ch. 1, §136). From the Greeks, the notion of a transcendent primary cause was incorporated into Judaic and Christian theology through to Modern science. ${ }^{43}$

I have argued that it is logically consistent to hold that 'God' is the primary cause of the existence of being (Aquinas Contra Gentiles, I, Ch. 49, §4). The conclusion came from the requirement to seek metaphysical account for the nonscientific problem of the existence of non-creating, contingent entities within created space-time.

Although not empirically testable, the faith position that 'God' creates meets the metaphysical postulate for a necessary and transcendent primary cause. This, I argue, is at least an attempt whereas physicalist accounts of cosmic origins remain in apparently 'uncaused' physical processes. I contend that the contra-argument begs the question (Aristotle On the Heavens):

It may seem evidence of excessive folly ... to try to provide an explanation of some things ... [This] criticism, however, is not always just ... [ for $w$ ] hen any one shall succeed in finding proofs of greater precision, gratitude will be due to him [sic]

42.'[A] process identifies the real with being, then identifies being with complete intelligibility, and finally identifies ... [that $]$ God ... accounts for everything else' (Lonergan 1970:675); Aquinas Summa Theologica, I, Q. 12, A. 1.

43.Aquinas Contra Gentiles, I, Ch. 79, §2; Armstrong (1999:56); Galilei ([1615] 2008:128); Newton (1846:504). 
for the discovery, but at present we must be content with a probable solution. (II, §5)

\section{Acknowledgements Competing interests}

The author declares that he has no financial or personal relationship(s) that may have inappropriately influenced him in writing this article.

\section{References}

Aquinas, Saint Thomas, [1264] 1955-1957a, Contra gentiles, Book one: God, transl. A.C. Pegis, ed., with English, especially Scriptural references, updated by J. Kenny, O.P., Hanover House, New York, NY.

Aquinas, Saint Thomas, [1264] 1955-57b, Contra gentiles, Book two: Creation, transl. J.F. Anderson, ed., with English, especially Scriptural references, updated by J. Kenny, O.P, Hanover House, New York, NY.

Aquinas, Saint Thomas, [c. 1259-1268] 1952, Quaestiones Disputatae de Potentia Dei: On the power of God, transl. English Dominican Fathers, The Newman Press, Westminster, MD, Html edn. J. Kenny, O.P., viewed 01 July 2013, from http://www. dhspriory.org/thomas/english/QDdePotentia.htm

Aquinas, Saint Thomas, [1264] 2010, Summa Theologica, complete American edn. transl. Fathers of the English Dominican Province, Kindle Edition, viewed 20 October 2012

Aristotle, [c. 350 BCE] n.d., Metaphysics, Book II, transl. W.D. Ross, viewed 30 October 2013, from http://classics.mit.edu/Aristotle/metaphysics.2.ii.html

Aristotle, [c. 350 BCE] n.d., Metaphysics, Book V, transl. W.D. Ross, viewed 15 August 2014, from http://classics.mit.edu/Aristotle/metaphysics.5.v.htm

Aristotle, [c. 350 BCE] 1922, On the heavens, Book II, transl. by J.L. Stocks, viewed 13 August 2013, from http://classics.mit.edu/Aristotle/heavens.2.ii.html

Armstrong, K., 1999, A history of God: From Abraham to the present: The 4000-year quest for God, Vintage Books, London.

Baldner, S.E. \& Carroll, W.E., 1997, Aquinas on creation: Writings on the 'sentences' of Peter Lombard: Book 2, Distinction 1, Question 1, Pontifical Institute of Mediaeval Studies, Toronto. (Medieval Sources in Translation 35).

Barrow, J.D., 2005, Impossibility: The limits of science and the science of limits, Vintage Books, London.

Blanchette, O., 2007, 'Metaphysics as preamble to religious belief', in C. Cunningham \& P.M. Candler (eds.), Belief and metaphysics, pp. 141-167, SCM Press, London.

Burrell, D.B., 2010, 'The act of creation with its theological consequences', in D.B. Burrell, C. Cogliati, J.M. Soskice \& W.R. Stoeger (eds.), Creation and the God of
Abraham, pp. 40-52, Cambridge University Press, Cambridge. http://dx.doi. Abraham, pp. 40-52, Cambridge Un
org/10.1017/CBO9780511778063.005

Carroll, S.M., 2011, Does the universe need God?, viewed 08 August 2013, from http://preposterousuniverse.com/writings/dtung/dtung.pdf

Clarke, W.N., 2007, The philosophical approach to God: A neo-Thomist perspective, 2nd rev. edn., Fordham University Press, New York, NY. http://dx.doi.org/10.5422/ fso/9780823227198.001.0001

Dampier, W.C., 1966, A history of science and its relations with philosophy \& religion, 4th edn., with a postscript by I. Bernard Cohen, Cambridge University Press, Cambridge.

Davies, P.C.W., 1998, 'What caused the big bang?', in J. Leslie (ed.), Modern Cosmology \& Philosophy, pp. 226-244, Prometheus Books, Amherst, NY

Diogenes Laertius, [1925] 1972, Lives of eminent philosophers, Book VII, Chapter 1 ZENO (333-261 B.C.), ed. R.D. Hicks, Harvard University Press, Cambridge, MA.

Ephrem the Syrian, Saint, 1990, Hymns on paradise, St. Vladimir's Seminary Press, Crestwood, NY.

Galilei, G., [1615] 2008, 'Letter to the Grand Duchess Christina', in M.A. Finocchiaro (ed.), The essential Galileo, pp. 109-145, Hackett Publishing Company, Inc., Indianapolis, IN \& Cambridge.

Gilson, É., [1937] 1999, The unity of philosophical experience, Ignatius, San Francisco, CA.

Haldane, J.J., 1996, 'Atheism and theism', in J.J.C. Smart \& J.J. Haldane (eds.), Atheism and theism, pp. 84-167, Blackwell Publishers Ltd, Oxford.

Hampson, D., 2009, 'Searching for God?', in J. Cornwell \& M. McGhee (eds.), Philosophers and God: At the frontiers of faith and reason, pp. 63-76, Continuum, London \& New York, NY.

Hartle, J.B. \& Hawking, S.W., 1983, 'Wave function of the universe', Physical Review D 28(12), 2960-2975. http://dx.doi.org/10.1103/PhysRevD.28.2960
Hawking, S.W., 1985, 'Response to letter to the editor of J.J. Tanner', Scientific American 73(1), 12.

Hawking, S.W., 1988, A brief history of time, Bantam Books, New York, NY.

Hawking, S.W. \& Ellis, G.F.R., 1973, The large scale structure of space-time, Cambridge University Press, Cambridge. http://dx.doi.org/10.1017/CBO9780511524646

Hawking, S.W. \& Mlodinow, L., 2010, The grand design: New answers to the ultimate questions of life, Bantam Press, London.

Hitchens, C., 2007, God is not great: How religion poisons everything, Warner Books, Inc., New York, NY.

Hume, D., [1748] 2008, An Enquiry Concerning Human Understanding, viewed 09 October 2013, from http://www.earlymoderntexts.com/pdf/humeenqu.pdf

Kant, I., [1783] 2007, Prologomena [= Preliminaries] to any future metaphysics that can present itself as a science, viewed 21 August 2014, from http://www. earlymoderntexts.com/pdfs/kant1783.pdf

Kant, I., [1787] 2010, The critique of pure reason, transl. J.M.D. Meiklejohn, The Pennsylvania State University, University Park, PA.

Krauss, L.M., 2012, A universe from nothing: Why there is something rather than nothing, with an afterword by R. Dawkins, Simon \& Schuster UK Ltd, London.

Kretzmann, N., 2001, The metaphysics of creation: Aquinas' natural theology in Summa Contra Gentiles II, Clarendon Press, Oxford. http://dx.doi. org/10.1093/0199246548.001.0001

Leibniz, G.W.F., [1698] 2006, Nature itself or the inherent force and activity of created things confirming and illustrating the author's dynamics, viewed 08 August 2013, from http://www.earlymoderntexts.com/pdf/leibnatu.pdf

Lonergan, B.J.F., 1970, Insight: A study of human understanding, 3rd edn., Philosophical Library, New York, NY

MacDonald, P.A., 2009, Knowledge and the transcendent: An inquiry into the mind's relationship to God, The Catholic University of America, Washington, DC.

MacIntyre, A., 2009, God, philosophy, universities: A selective history of the Catholic philosophical tradition, Rowman \& Littlefield Publishers, Inc., Lanham, MD.

Marcel, G., [1950] 2001, The mystery of being: I: Reflection and mystery, St. Augustine's Press, South Bend, IN.

Maritain, J., [1959] 1995, Distinguish to unite or the degrees of knowledge, transl. 4th French edn. under the supervision of G.B. Phelan, presented by R. McInerny, University of Notre Dame Press, Notre Dame, IN.

Medawar, P.B., 1984, The limits of science, Oxford University Press, Oxford.

Murphy, N., 2008, 'Emergence, downward causation, and divine action', in R.J. Russell, N. Murphy \& W.R. Stoeger (eds.), Scientific perspectives on divine action: Twenty years of challenge and progress, pp. 111-131, The University of Notre Dame Press, Notre Dame, IN.

Newton, I., 1846, The mathematical principles of natural philosophy, to which is added: Newton's system of the world, transl. A. Motte, first American edn., Daniel Adee, New York, NY.

Nichols, T., 2010, 'Understanding the Creator from the things that are made', Logos: A Journal of Catholic Thought and Culture 13(4), 156-175. http://dx.doi. org/10.1353/log.2010.0007

Peacocke, A., 2008, 'Some reflections on scientific perspectives on divine action', in R.J. Russell, N. Murphy \& W.R. Stoeger (eds.), Scientific perspectives on divine Action: Twenty years of challenge and progress, pp. 201-223, The University of Notre Dame Press, Notre Dame, IN.

Penrose, R., 2004, The road to reality: A complete guide to the laws of the universe, Vintage Books, New York, NY.

Plato, [260 BC] 1925, Plato in twelve volumes, vol. 9, transl. W.R.M. Lamb, Harvard University Press, Cambridge, MA.

Rescher, N., 1984, The limits of science, University of California Press, Berkeley, CA.

Roos, M., 2008, 'Expansion of the universe: Standard big bang model', UNESCO Encyclopedia of Life Supporting Systems (EOLSS), viewed 01 March 2014, from http://arxiv.org/pdf/0802.2005v1.pdf

Russell, R.J., 2008, Cosmology: From alpha to omega, Fortress Press, Minneapolis, $\mathrm{MN}$.

Smart, J.J.C., 1996, 'Atheism and theism', in J.J.C. Smart \& J.J. Haldane (eds.), Atheism and theism, pp. 6-83, Blackwell Publishers Ltd., Oxford.

Spitzer, R.J., 2010, New proofs for the existence of God: Contributions of contemporary physics and philosophy, William B. Eerdmans Publishing Company, Grand Rapids, MI \& Cambridge.

Stoeger, W.R., 2008, 'Conceiving divine action in a dynamic universe', in R.J. Russell, N. Murphy \& W.R. Stoeger (eds.), Scientific perspectives on divine action: Twenty years of challenge and progress, pp. 225-247, The University of Notre Dame Press, Notre Dame, IN.

Susskind, L., 2012, Was there a beginning?, viewed 01 March 2014, from http://arxiv. org/pdf/1204.5385v1.pdf

Weinberg, S., 1993, The first three minutes: A modern view of the origin of the universe, updated edn., Basic Books, New York, NY. 